\title{
Better use of available radiology resources for women's health in Latin America and the Caribbean
}

\author{
Kayiba Peggy Medlen, ${ }^{1}$ Nancy Anne Leahy, ${ }^{2}$ Kerry Greene-Donnelly, ${ }^{3}$ Howard \\ Bruce Fleishon, ${ }^{4}$ and Pablo Jiménez ${ }^{1}$
}

Suggested citation Medlen KP, Leahy NA, Greene-Donnelly K, Fleishon HB, Jiménez P. Better use of available radiology resources for women's health in Latin America and the Caribbean. Rev Panam Salud Publica. 2018;42:e115. https://doi.org/10.26633/RPSP.2018.115

ABSTRACT Despite the United Nations Millennium Development Goals and the 2030 Sustainable Development Goals, women in numerous countries still face many challenges in obtaining good-quality health care. For example, various nations in Latin America and the Caribbean (LAC) do not have access to complex radiology technologies. However, conventional radiography, ultrasound, mammography, and computed tomography are available and can be used to address such women's health concerns as breast and cervical cancers, postpartum bleeding, and tuberculosis. LAC countries face additional difficulties in radiology services with respect to quality human resources, quality assurance programs, standardization, and functioning of diagnostic imaging units. These deficiencies affect the quality of the services rendered. Appropriate measures must be implemented to produce quality services and quality images and to reduce adverse events. These steps will ensure better outcomes and consequently reduce mortality and morbidity.

Keywords Women's health; radiology; ultrasonography; tomography, x-ray computed; mammography; Latin America; West Indies.

The United Nations Millennium Development Goals to combat diseases and discrimination against women were

\footnotetext{
Department of Health Systems and Services/Unit of Medicines and Health Technologies, Radiological Health Program, Pan American Health Organization, Washington, D.C., United States of America. Send correspondence to Kayiba Peggy Medlen, at medlenk@paho.org

2 Austin, Texas, United States of America.

3 Upstate Medical University, Syracuse, New York, United States of America.

4 Emory St. Joseph's Hospital, Department of Radiology, Atlanta, Georgia, United States of
} America. to be achieved by the year 2015 (1). Although there has been progress, many countries have fallen short of attaining those objectives. According to a recent study conducted in New Delhi, India, over $90 \%$ of women reported experiencing some form of sexual violence, while around $80 \%$ experienced verbal sexual harassment (2). Of the women living around the world, over 700 million of them married when they were under the age of 18, including an estimated 250 million who were married prior to their $15^{\text {th }}$ birthday (3). A European Union survey ascertained that $34 \%$ of women with a health issue or disability were victims of violence by a partner (4). In 2013, the global employment-to-population ratio was $72 \%$ for men and $47 \%$ for women (5). Between 1990 and 2010, there were fewer than 100 peace agreements containing any reference to women (6).

In 2015, a special issue of this scientific journal focused on women's health concerns, including maternal death, severe maternal morbidity, femicide, physical and sexual violence, regional and ethnic inequalities, mental health, HIV, aging, 
suicide, obesity, breast cancer, and alcohol use (7). Some health challenges and diseases affect both women and men. However, women experience pregnancy and childbirth, which can carry health risks and require access to care tailored specifically to their needs. Moreover, women face greater difficulties in obtaining health care and protecting their health, due to gender inequalities in education, income, employment, and many other areas (8).

Radiology plays a crucial role in primary care, as it is used for screening, diagnosis, management, and treatment of many diseases. Nevertheless, radiology must be used correctly to reach its full potential in medicine and public health. With timely and accurate diagnosis, radiology can reduce mortality and morbidity, thus improving the health of the population and reducing health care costs (9). Many Latin American and Caribbean countries face a number of challenges, including a lack of quality assurance programs and standardization, a shortage of qualified human resources, and a lack of functioning and updated equipment, all of which has led to suboptimal radiology services.

This article will focus on the use of mammography, ultrasound, and computed tomography in the screening, diagnosis, and management of three health issues faced by women: breast cancer, cervical cancer, and postpartum hemorrhage. The piece also discusses the use of available imaging modalities with additional health issues that affect women: injuries and violence, tuberculosis, and cardiovascular diseases. Throughout the article, there is an emphasis on the need for a robust quality assurance program in radiology. The content for the piece was obtained through an extensive literature review by the authors, who are experienced in their respective fields.

\section{QUALITY ASSURANCE}

Around the world, many people lack access to radiology services. And, even when those services are available, both the quality and safety of the procedures can be questionable (10). Access to equipment is a real challenge in many countries of Latin America and the Caribbean (LAC). There is a vast disparity between low-income countries and high-income nations in their access to nuclear medicine (NM), magnetic resonance imaging (MRI), single-photon emission computed tomography-computed tomography (SPECT-CT), positron emission tomography-computed tomography (PET-CT), and positron emission tomography-magnetic resonance imaging (PET-MRI). Some $10 \%$ of countries have at least one PET scanner, $33 \%$ have at least one linear accelerator, and $54 \%$ have at least one MRI unit (11). In some countries, nearly $80 \%$ of health care equipment is donated or funded by international contributors or foreign governments, but only $10 \%$ to $30 \%$ of donated equipment becomes operational (11).

Due to the limited access to certain technologies, the use of conventional $X$ ray, ultrasound, mammography, and computed tomography (CT) is crucial, but they must be used properly to produce expected outcome. Toward that end, quality assurance (QA) programs can play a significant role in radiology by consistently enhancing the quality of the images, with minimum exposure to patients and workers, as well as improving the services as a whole (12).

In a robust, effective radiology QA program, both the approach to testing of radiology equipment (quality control technique) and the implementation of guidelines (quality administration procedure) must be completed correctly. The World Health Organization (WHO) defines an adverse medical event as an incident resulting in harm to patients (13). In radiology, an adverse event can take many forms. Among these are: 1) a threat to patient safety brought about by inaccurate and untimely diagnosis; 2) unjustified and repeated radiation exposure; 3) incorrect labeling of radiographic images; 4) poor technique in the execution of the exam; 5) lack of knowledge; 6) error in the interpretation of a radiograph (including misdiagnosis or failure to diagnose, failure to suggest an appropriate procedure, and failure to communicate in a timely and clinically appropriate manner); and 7) exposure to health care-associated infections (14). Without a QA program, the many crucial aspects of image process will be compromised. This can make the services suboptimal, with such problems as lack of quality control testing; poorly trained human resources; a complete lack of supervision or accountability; a lack of design of imaging protocols; an absence of policies and procedures for patient management; and a lack of safety and reporting standardization.

Quality assurance in medical imaging began in the early 1900s with processor monitoring procedures, and it continues today with practices in image quality evaluation and dose monitoring. In 2011, eight intergovernmental organizations agreed by consensus on the Radiation Protection and Safety of Radiation Sources: International Basic Safety Standards (BSS) (15). Among the technical requirements of the BSS is the need to implement a comprehensive program of quality assurance for medical exposures. This program should be implemented with the active participation of medical physicists, radiological medical practitioners, medical radiation technologists, radiopharmacists and radiochemists (for complex nuclear medicine facilities), and, as appropriate, also in conjunction with other health professionals. The program should also take into account the principles established by $\mathrm{WHO}$, the Pan American Health Organization (PAHO), and relevant professional bodies.

For many in the medical imaging environment, governmental regulations dictate QA processes to ensure patient safety and a minimum image quality standard, as well as training and education requirements for radiologists, physicists, and technologists/radiographers. In addition to or in place of governmental regulations, many professional groups provide guidelines or accreditation programs to aid in the process and to document achievement of quality imaging services. The American College of Radiology and the Intersocietal Accreditation Commission offer accreditation programs for multiple imaging modalities. In addition, the American Association of Physicists in Medicine and the Radiological Society of North America provide ample resource to support a QA program (Table 1).

Establishing appropriate QA practices ensures proper equipment operation for radiation safety, image quality for viewing, and, ultimately, accurate interpretation and diagnosis. All modalities, including radiography, $\mathrm{CT}$, MR, nuclear medicine, and ultrasound, have QA programs. It is essential to have a cultural shift in which all radiology workers and health authorities assume responsibility 
TABLE 1. Some of the radiology professional groups providing guidelines or accreditation, with the corresponding Internet address

\begin{tabular}{|c|c|}
\hline Group & Internet address \\
\hline American Association of Physicists in Medicine & http://aapm.org/pubs/CTProtocols/ \\
\hline American College of Radiology & http://www.acraccreditation.org/Modalities/CT \\
\hline Intersocietal Accreditation Commission & https://www.intersocietal.org/ct/seeking/ct_standards.htm \\
\hline Radiological Society of North America & http://rsna.org \\
\hline International Atomic Energy Agency & https://www.iaea.org/ \\
\hline European Commission & https://cordis.europa.eu/news/rcn/8983_en.html \\
\hline
\end{tabular}

Source: Prepared by the authors of this article.

for the quality, efficiency, and safety improvements in order to minimize or eliminate adverse events.

\section{THE ROLE OF IMAGING MODALITIES IN WOMEN'S HEALTH}

\section{Breast cancer and mammography}

In the Americas in 2012, more than 408200 women were diagnosed with breast cancer, and 92000 women died from this disease, with around $46 \%$ of these deaths occurring in LAC countries (16). Breast cancer mortality in high-income countries is often low due to better-quality detection and treatment. Despite the improvements in breast cancer care made in the past 20 years with early screening diagnosis and treatment, breast cancer mortality is still high in LAC nations (16). Mammography is the imaging technology of choice since it has led to earlier diagnosis and a $20 \%$ reduction in breast cancer mortality (17). Early detection of breast cancer by using mammography also leads to a greater range of treatment options, including less extensive surgery and the use of chemotherapy with fewer serious side effects, or even, in some cases, the option to forgo chemotherapy (18).

Approximately $61 \%$ of breast cancers diagnosed at a localized stage have a five-year relative survival rate of $99 \%$ (18). This demonstrates the clear correlation between cancer stage at diagnosis and the overall survival rate. In some LAC countries, an estimated $50 \%$ of detected breast cancer is in advanced stages (stage III or IV). In comparison, in Sweden, fewer than $10 \%$ of breast cancers are detected in advanced stages (19). Diagnosing cancers at an early stage improves overall patient survival. In Canada, fewer than $10 \%$ of patients diagnosed in early stages had a poor outcome, versus $49 \%$ for patients diagnosed at stage IV (20). The economic burden of breast cancer in LAC is difficult to estimate, but costs for treating patients with stage IV breast cancer are likely to be around three to four times higher than those for patients with stage I breast cancer (19).

Mammography plays a defining role in diagnosing breast cancer, particularly in earlier stages. For this purpose, mammography images must be performed and interpreted with strict adherence to QA programs and quality control (QC) measures in order to ensure the most accurate diagnoses for all patients. A well-organized screening program should include the acquisition of mammography units, but also provide an environment that will permit detection of breast cancer at the earliest, most treatable stage (16). QA programs can minimize adverse events by limiting the production of images of poor quality and inaccurate diagnoses that can delay the detection of breast cancer at an early, treatable stage. A PAHO manual titled Mammography Services Quality Assurance: Baseline Standards for Latin America and the Caribbean (21) can be used as a guide for such services. A culture of patient safety is crucial, especially regarding the quality of the images produced and radiation exposure. The diagnostic information acquired is proportional to the image quality. Therefore, that quality plays a crucial role in early detection, patient treatment, and increased chances of survival.

\section{Breast ultrasound for the detection of cancer}

Although screening mammography has been found to decrease mortality from breast cancer, it is an imperfect tool for women with dense breast tissue, as characterized by breast density Breast
Imaging-Reporting and Data Systems (BI-RADS) categories 3 and 4 (22). Multiple studies have compared breast cancer detection with mammography-only versus mammography supplemented with whole-breast screening ultrasound exams imaging. These studies have found whole-breast ultrasound screening increased detection of small, invasive, node-negative cancers over the use of mammography alone in women with dense breast tissue $(22,23)$. Additionally, the American College of Radiology Imaging Network (ACRIN) performed a prospective international multicenter research study in which it compared the findings of mammography and hand-held, high-resolution ultrasound exams, irrespective of breast density, in identifying breast cancers. The study concluded that the total number of cancers identified was comparable: 58 of $111(52.3 \%)$ for ultrasound and 59 of $111(53.2 \%)$ for mammography (24).

The many benefits of ultrasound, such as its portability, cost, and nonionizing radiation, allow it to be a readily available imaging modality in developing countries. The results of multiple studies support the sensitivity of whole-breast screening ultrasound to identify cancer and show that the technique could be a viable alternative in countries without mammography equipment. However, image acquisition and interpretation requires a significant amount of training and time. QA programs, imaging standards, and training should be considered prior to implementing whole-breast ultrasound screening exams (24).

\section{Cervical cancer}

Cervical cancer is a worldwide public health concern, with the greatest impact occurring in low- and middle-income countries, including LAC ones (25). A comprehensive analysis on cervical cancer in LAC that was published in 2004 reported that approximately 30000 women died from cervical cancer and 70000 new cases were diagnosed each year (25). By 2025 the number of new cases of cervical cancer is projected to increase $75 \%$ in LAC (26).

The numbers of individuals who succumb to cervical cancer are much higher in low- and middle-income countries due to the lack of widespread screening programs as well as a higher percentage of infections with human papilloma 
virus (HPV) types 16 and 18, which are known to have greater cancer-causing potential $(25,26)$. Many cervical cancers in these nations are diagnosed in the later, more advanced stages when appropriate screening is unavailable. Developed countries have vast screening programs that find cervical cancers at the earliest, most treatable stages, resulting in fewer deaths (25).

The most significant risk factor for cervical cancer is HPV infection, contracted through unsafe sexual practices (26). Additionally, smoking, HIV infection, and long-term use of oral contraceptives are contributing risk factors for cervical cancer (26). Without HPV infection, the development of cervical cancer is quite low. Since 2002, an HPV vaccine has been available to prevent HPV infection and therefore cervical cancers. According to Clifford et al. (27), vaccination against HPV types 16 and 18 could prevent $70 \%$ of worldwide invasive cervical cancer. When vaccination is not desired, is contraindicated, or is unavailable, averting transmission by use of education and safe sexual practices is the key to infection prevention.

\section{Computed tomography for cervical cancer detection}

When cervical cancer preventative measures have failed, it is imperative to have the highest-quality detection and treatment available. Without screening programs that use Papanicolaou (Pap) smear examination, diagnosis of cervical cancer is performed through clinical examination, biopsy, and histopathology. The International Federation of Gynecology and Obstetrics (FIGO) developed a staging system that incorporates clinical, histological, and radiologic data (not including PET, MRI, or CT imaging) to stage cervical cancer (28).

Medical imaging modalities are instrumental in the treatment planning process and follow-up of cervical cancer patients. The use of PET, MRI, and CT aid in the assessment of disease spread and the need for surgical intervention. PET imaging is useful in lymph node evaluation, whereas MRI assesses tumor size and parametrical involvement (28). It is recognized that both PET and MRI are superior imaging modalities in the assessment of cervical cancer. According to the American College of Radiology (ACR) appropriateness criteria, MRI (without and with intravenous (IV) contrast) is the highest-rated imaging exam, PET-CT is second, and IV-enhanced CT is third (28). However, because MRI and PET are not readily available in most of the $\mathrm{LAC}$ region, the use of CT is appropriate (28). $\mathrm{CT}$ is not a valuable tool in the early stages of cervical cancer, but it is helpful in late-stage assessment and in the detection of lymph node involvement. The ACRIN reported a $42 \%$ sensitivity for detecting advanced cervical cancer utilizing CT (27). Identification of lymph node involvement utilizing CT has a sensitivity of $31 \%$ and a specificity of $86 \%$ (28). CT also provides information on distant metastases and supplies a road map for interventional procedures (28). It is important to note that although CT is not the "gold standard" in cervical cancer imaging, when performed at the highest level, CT imaging can aid in the appropriate treatment of the patient.

QA programs can minimize adverse events and provide high-quality CT exams through protocol review, image quality analysis, and monitoring of scanner-generated dose reports. A journal editorial by Wintermark and Lev (29) described the overexposure of more than 200 patients during CT perfusion scans at one facility, resulting in epilation in many of those persons. This occurrence highlights the types of adverse events that can result from imaging programs that are poorly monitored and lack quality assurance oversight. In CT, the optimization of quality and dose can only be achieved through the use of modern CT scanners possessing both the hardware and software necessary to provide low-exposure exams at diagnostic image quality.

Treatment options for cervical cancer include chemoradiotherapy (where available), surgery, or a combination of the two. When diagnosis is performed and treatment given, $80 \%$ to $95 \%$ of women with early stage disease (stages I and II) and $60 \%$ with stage III disease can be cured (30).

\section{Postpartum hemorrhage}

Decreasing maternal mortality rates (MMRs) from preventable causes has been a global priority, beginning with the UN Millennium Development Goals (MDGs) in 2000 and continuing with the Sustainable Development Goals (SDGs), which were established in 2016. Although substantial progress had been made under the MDGs, the MMR is still at an unacceptable level, with approximately 830 women dying each day worldwide from preventable causes related to pregnancy and childbirth (31). The most common cause of maternal mortality is postpartum hemorrhage (31).The data collected on the MMR demonstrates that $99 \%$ of all preventable maternal deaths occur in low-resource countries, with the highest risk being for adolescent girls under the age of 15 and for females who live in rural and poor communities (32). The disparity in maternal outcomes is directly related to differences in access to health care, particularly quality obstetric care and services $(32,33)$.

\section{Postpartum hemorrhage and ultrasound}

Ultrasound is part of routine prenatal care in developed countries. This imaging technique can accurately date a pregnancy; identify fetal abnormalities, malpresentation, multiple gestations, and placenta previa; and allow a physician to manage the pregnancy properly and improve outcomes (33). Ultrasound is the imaging modality of choice for the postpartum patient who is febrile or experiencing complications such as vaginal discharge, bleeding, and pain $(34,35)$. In many developing countries-especially in rural communities-obstetric services, including ultrasound services and trained individuals to perform the exams, are extremely limited or nonexistent, leaving women vulnerable to poor outcomes. QA programs in ultrasound minimize adverse events by ensuring proper functioning of the ultrasound equipment for consistency of ultrasound images and accuracy of measurement devices, reducing the number of nondiagnostic exams.

Hemorrhage is the leading cause (23.1\%) of maternal deaths in LAC, with $57 \%$ of the deaths in the postpartum period (32). Postpartum hemorrhage $(\mathrm{PPH})$ is divided into primary $\mathrm{PPH}$ (defined as within 24 hours after delivery) and secondary PPH (defined as more than 24 hours after delivery, up through the sixth postpartum week). Postpartum hemorrhage causes can be further delineated into four general classifications: tone, trauma, tissue, and thrombin (36). Determining the etiology of $\mathrm{PPH}$ is essential for determining the appropriate treatment and management and, consequently, for decreasing MMR. 
Primary $\mathrm{PPH}$ due to uterine atony makes up $70 \%$ of all PPH cases (36). Utilization of uterotonic drugs and active management of the third stage of labor are strategies to address primary $\mathrm{PPH}$ associated with uterine atony (36). Sonography of the postpartum uterus can be used to identify other causes of $\mathrm{PPH}$, such as retained products of conception, arteriovenous (AV) malformations, endometritis, abscess, wound cellulitis, and surgical complications (including hematoma, pseudoaneurysms, and uterine scar dehiscence) (35). Imaging studies are used to identify the source of bleeding and to help determine if surgical intervention is warranted (35). High-quality images and well-trained staff are imperative to ensuring an accurate diagnosis. The interpretation of sonographic studies of the postpartum uterus can be complicated, as there is significant overlap between pathologic and normal physiologic changes of the uterus. However, utilizing ultrasound to evaluate symptomatic patients can facilitate early intervention and treatment and lead to a decrease in MMRs $(31,37)$.

\section{THE USE OF AVAILABLE IMAGING MODALITIES WITH ADDITIONAL DISEASES THAT AFFECT WOMEN}

Most LAC countries have limited access to advanced radiology imaging equipment; however, conventional radiology units, CT scanners, and ultrasound equipment are available and, when used appropriately, can facilitate and expedite diagnosis. Further research is needed to determine how these imaging modalities can be utilized effectively in the diagnosis of a wide spectrum of medical concerns.

In addition to the diseases or conditions already mentioned, there are others that affect women for which imaging technologies can be helpful. Table 2 highlights some of the ailments where ultrasound, CT, and radiography can be useful for accurately detecting abnormalities and managing the disease.

\section{DISCUSSION AND CONCLUSIONS}

Radiology is used for screening, diagnosis, management, and treatment of many diseases that threaten the health and well-being of a population. To assist LAC countries, an integrated approach must be utilized in public health, with the inclusion of quality radiology services to reduce morbidity and mortality. A good-quality image is critical to achieving an accurate diagnosis in radiology services. Acquisition of equipment alone does not constitute quality radiology services or the production of quality images. QA programs and standardization are essential; without them, the services offered will be suboptimal, leading to poor outcomes.
Also important are the proper interpretation of images and adequate and timely communication between the radiologist and referring physicians and other clinicians. The delivery of preventative radiology services requires: 1 ) recognizing the value of radiology in both specialized and primary care; 2) teamwork in providing quality, patient-centered radiology services that maximize the impact on population health, as well as for each patient; and 3) leadership that fosters a culture of quality and service for patients, who depend on these services to live healthy, productive lives.

There are no shortcuts to patient safety and quality of care. With inaccurate and late diagnoses, unnecessary radiation exposure, and other adverse events, the patient becomes a victim not only of the disease but also of the services that fail to provide proper health care. Radiology can offer many clinical benefits, but poor services can result in high cost for both the health care system and patients. The 2030 Sustainable Development Goal on Good Health and Well-being aims to reduce or end maternal mortality, noncommunicable diseases (NCDs), road traffic deaths, and TB and other infectious diseases, as well as to provide access to quality essential health care services (39). The role of radiology in women's health cannot be underestimated or ignored. Available technologies, such as conventional radiography, ultrasound, mammography, and $\mathrm{CT}$, are able to detect and deal with many diseases and

TABLE 2. The use of available imaging with additional diseases that affect women

\begin{tabular}{|c|c|c|c|}
\hline Disease/Condition & Ultrasound & Computed tomography (CT) & Conventional $\mathrm{X}$ ray \\
\hline Injuries/Violence & $\begin{array}{l}\text { Ultrasound of extremities can be used to } \\
\text { identify hematomas, deep vein thrombosis, } \\
\text { and arteriovenous malformation. } \\
\text { Ultrasound of thorax or abdomen can } \\
\text { look for free fluid. }\end{array}$ & $\begin{array}{l}\text { CT provides high-quality imaging of } \\
\text { musculoskeletal injuries such as fracture/ } \\
\text { dislocation. Injury to soft tissue organs, } \\
\text { such as liver and kidney, are also assessed } \\
\text { with CT. Head trauma, hematomas, } \\
\text { contusions, and hemorrhage are } \\
\text { effectively diagnosed with CT. }\end{array}$ & $\begin{array}{l}\mathrm{X} \text { ray of affected anatomy can be used to } \\
\text { assess fractures and/or foreign bodies. }\end{array}$ \\
\hline Tuberculosis (TB) & $\begin{array}{l}\text { Ultrasound of the chest can detect pleural } \\
\text { and pericardial effusion, localize area for } \\
\text { drainage, and locate subpleural nodules } \\
\text { and lung consolidations (38). }\end{array}$ & $\begin{array}{l}\mathrm{CT} \text { is beneficial in the assessment of patients } \\
\text { with lymphadenopathy, pleural effusions, and } \\
\text { cavitation. }\end{array}$ & $\begin{array}{l}\text { Chest } X \text { ray may be sufficient for diagnosis } \\
\text { in the appropriate clinical setting for } \\
\text { primary pulmonary tuberculosis. }\end{array}$ \\
\hline Cardiovascular diseases (CVDs) & $\begin{array}{l}\text { Ultrasound evaluation, including Doppler } \\
\text { waveforms of the blood vessels, can } \\
\text { identify plaque, hemodynamically } \\
\text { significant stenosis, and/or occlusion. } \\
\text { Ultrasound exam of the heart is used to } \\
\text { identify structural and functional } \\
\text { abnormalities of the valves, chambers, } \\
\text { and muscles. }\end{array}$ & $\begin{array}{l}\text { CT demonstrates calcified vessels in the } \\
\text { body as well as heart (calcium scoring). } \\
\text { Additionally, imaging of arterial stenosis, } \\
\text { dissection, or aneurysm can be } \\
\text { accomplished with CT angiography imaging. }\end{array}$ & $\begin{array}{l}\text { Chest } X \text { ray will show fluid in or around } \\
\text { lungs. Among other chest abnormalities } \\
\text { that can be identified on a chest } X \text { ray are } \\
\text { an enlarged heart, aortic aneurysm, and } \\
\text { calcium buildup in the heart or blood } \\
\text { vessels. }\end{array}$ \\
\hline
\end{tabular}

Source: Prepared by the authors of this article. 
conditions of public health concern. However, the services must be of quality in order to produce the desired outcomes.
Conflicts of interest. None declared.

Disclaimer. Authors hold sole responsibility for the views expressed in the manuscript, which may not necessarily reflect the opinion or policy of the RPSP/PAJPH or PAHO.

\section{REFERENCES}

1. World Health Organization. Millennium Development Goals (MDGs). Geneva: WHO; 2000. Available from: http:/ / www. who.int/topics/millennium_development_goals/en/ Accessed 22 February 2018.

2. UN Women. Safe Cities Global Initiative. Available from: http://www. unwomen.org/ /media/headquarters/ attachments/sections/library/publications / 2013/12/un\%20women-evawsafecities-brief_us-web\%20pdf.ashx Accessed 22 February 2018.

3. United Nations Children's Fund. Ending child marriage: progress and prospects. New York: UNICEF; 2014. Available from: https://www.unicef.org/media/files / Child_Marriage_Report_7_17_LR..pdf Accessed 22 February 2018.

4. European Union Agency for Fundamental Rights. Violence against women: an EU-wide survey: main results. Available from: http:/ / fra.europa.eu/sites/default/ files / fra-2014-vaw-survey-main-resultsapr14_en.pdf Accessed 22 February 2018.

5. International Labour Organization. Global employment trends 2014. Geneva: ILO; 2014. Available from: http://www.ilo. org/wcmsp5/groups / public/---dgreports/---dcomm/---publ/documents/ publication/wcms_233953.pdf Accessed 22 February 2018.

6. Bell C, O'Rourke C. Peace agreements or pieces of paper? The impact of UNSC resolution 1325 on peace processes and their agreements. Int Comp Law Q. 2010;59(4):941-80.

7. Etienne CF. A new agenda for women's health in the Americas. Rev Panam Salud Publica. 2015 May;37(4-5):197-8.

8. World Health Organization. Women and health: today's evidence tomorrow's agenda Geneva: WHO; 2009. Available from: http://www.who.int/ gender/women_health_report/full report_20091104_en.pdf Accessed 22 February 2018

9. Balogh EP, Miller BT, Ball JR, eds. Overview of diagnostic error in health care. In: Balogh EP, Miller BT, Ball JR, eds. Improving diagnosis in health care. Washington, D.C.: National Academies Press; 2015:81-144.

10. World Health Organization, Department of Essential Health Technologies. Essential diagnostic imaging. Available from: https://web.archive.org/web/ 20121023154427/http:/ / www.who.int/ eht/en/DiagnosticImaging.pdf Accessed 22 February 2018.

11. World Health Organization. Global atlas of medical devices. Geneva: WHO; 2017.

12. Pan American Health Organization, Radiological Health Program. Quality assurance in radiology facility. Available from: http://www.paho.org/hq/index. php?option $=$ com_content $\&$ view $=$ art icle\&id $=3364 \% 3$ A2010-programas-garantia-calidad\&catid $=1162 \% 3$ Aradiological-program\&lang=en Accessed 22 February 2018.

13. World Health Organization. Definitions of key concepts from the WHO patient safety curriculum guide (2011). Available from: http:/ / www.who.int/patientsafety/education/curriculum/course1a_handout. pdf Accessed 22 February 2018.

14. Pinto A, Brunese L, Pinto F, Reali R, Daniele S, Romano L. The concept of error and malpractice in radiology. Semin Ultrasound CT MR. 2012 Aug;33(4):275-9. doi: 10.1053/j.sult.2012.01.009.

15. European Commission; Food and Agriculture Organization of the United Nations; International Atomic Energy Agency; InternationalLabourOrganization; OECD Nuclear Energy Agency; Pan American Health Organization; United Nations Environment Programme; World Health Organization. Radiation protection and safety of radiation sources: international basic safety standards. Vienna: IAEA; 2014.

16. Pan America Health Organization. Breast cancer in the Americas. Available from: http://www.paho.org/hq/index. php?option $=$ com_docman\&task $=$ doc download\&Itemid $=270 \&$ gid $=19075 \& l a-$ ng=en Accessed 22 February 2018

17. World Health Organization. Position paper on mammography screening. Geneva: WHO; 2014. Available from: http:/ / www.who.int/cancer/publications/mammography_screening/en/ Accessed 22 February 2018.

18. American Cancer Society. Cancer treatment \& survivorship facts \& figures 2016-2017. Atlanta: ACS; 2016. Available from: https://www.cancer.org/content/ $\mathrm{dam} / \mathrm{cancer}$-org/research/cancerfacts-and-statistics/cancer-treatment-andsurvivorship-facts-and-figures / cancer-treatment-and-survivorshipfacts-and-figures-2016-2017.pdf Accessed 22 February 2018.

19. Justo N, Wilking N, Jönsson B, Luciani $S$, Cazap E. A review of breast cancer care and outcomes in Latin America. Oncologist. 2013;18(3):248-56.

20. Mittmann N, Porter JM, Rangrej J, Seung SJ, Liu N, Saskin R, et al. Health system costs for stage-specific breast cancer: a population-based approach. Curr Oncol. 2014 Dec;21(6):281-93. doi: 10.3747/ co.21.2143.

21. Pan American Health Organization. Mammography services quality assurance: baseline standards for Latin America and the Caribbean. Washington, D.C: PAHO; 2016.

22. Brem RF, Lenihan MJ, Lieberman J Torrente J. Screening breast ultrasound: past, present, future. AJR Am J Roentgenol. 2015 Feb;204(2):234-40. doi: 10.2214/ AJR.13.12072.

23. Berg WA, Bandos AI, Mendelson EB, Lehrer D, Jong RA, Pisano ED. Ultrasound as the primary screening test for breast cancer: analysis from ACRIN 6666. J Natl Cancer Inst. 2015 Dec 28;108(4). pii: djv367. doi: 10.1093/jnci/djv367.

24. Mendelson EB, Berg, WA. Training and standards for performance, interpretation, and structured reporting for supplemental breast cancer screening. AJR Am J Roentgenol. 2015 Feb;204(2):265-8.

25. Lewis MJ. A situational analysis of cervical cancer in Latin America and the Caribbean. Washington, D.C.: Pan American Health Organization; 2004

26. Almonte $M$, Albero G, Molano $M$ Carcamo C, García P, Pérez G. Risk factors for human papillomavirus exposure and co-factors for cervical cancer in Latin America and the Caribbean. Vaccine. 2008;26:L16-L36.

27. Clifford G, Smith J, Plummer M, Muñoz N, Franceschi S. Human papillomavirus types in invasive cervical cancer worldwide: a meta-analysis. Br J Cancer. 2003;88(1):63-73.

28. American College of Radiology. ACR Appropriateness Criteria. Available from: https:/ / acsearch.acr.org/docs / 69461/ Narrative/ Accessed 22 February 2018.

29. Wintermark M, Lev MH. FDA investigates the safety of brain perfusion CT. AJNR Am J Neuroradiol. 2010 Jan;31(1):2-3. doi: 10.3174/ajnr.A1967.

30. Petignat P, Roy M. Diagnosis and management of cervical cancer. BMJ. 2007; 335(7623):765-8.

31. World Health Organization. Maternal mortality key facts. Available from: http://www.who.int/mediacentre/factsheets/fs348/en/ Accessed 22 February 2018.

32. World Health Organization. Annex A. Summaries of the SDG health and health-related targets. Available from: http: / / www.who.int/gho/publications / world_health_statistics/2016/EN WHS2016_AnnexA.pdf?ua=1 Accessed 22 February 2018.

33. Stanton K, Mwanri L. Global maternal and child health outcomes: the role of obstetric ultrasound in low resource settings. World J Prev Med. 2013;1(3):22-9.

34. Adkins K, Minardi J, Setzer E, Williams D. Retained products of conception: an atypical presentation diagnosed immediately with bedside emergency ultrasound. Case 
Rep Emerg Med. 2016;2016:9124967. doi: 10.1155/2016/9124967.

35. Laifer-Narin SL, Kwak E, Kim H, Hecht EM, Newhouse JH. Multimodality imaging of the postpartum or posttermination uterus: evaluation using ultrasound, computed tomography, and magnetic resonance imaging. Curr Probl Diagn Radiol. 2014 Nov-Dec;43(6):374-85. doi: 10.1067/j. cpradiol.2014.06.001.

36. Lalonde A; International Federation of Gynecology and Obstetrics. Prevention and treatment of postpartum hemorrhage in low-resource settings. Int J Gynaecol Obstet. 2012 May;117(2):108-18. doi: 10.1016/j.ijgo.2012.03.001.

37. Plunk M, Lee JH, Kani K, Dighe M. Imaging of postpartum complications: a multimodality review. AJR Am J Roentgenol. 2013 Feb;200(2):W143-54. doi: 10.2214/AJR.12.9637.

38. Agostinis P, Copetti R, Lapini L, Monteiro B, N'Deque A, Baritussio A. Chest ultrasound findings in pulmonary tuberculosis. Trop Doct. 2017 Oct;47(4):320-8. doi: $10.1177 / 0049475517709633$.
39. United Nations. Sustainable Development Goals: 17 goals to transform our world. Available from: http://www.un.org/ sustainabledevelopment/ Accessed 22 February 2018.

Manuscript received on 7 March 2018. Revised version accepted for publication on 7 May 2018.

RESUMEN A pesar de los Objetivos de Desarrollo del Milenio y los Objetivos de Desarrollo Sostenible para el 2030 de las Naciones Unidas, en muchos países las mujeres todavía tienen grandes dificultades para acceder a una atención de salud de buena calidad.

Mejora en el uso de los recursos radiológicos disponibles para la atención de salud de la mujer en América Latina y el Caribe

Palabras clave
Por ejemplo, varios países de América Latina y el Caribe no tienen acceso a las técnicas radiológicas más complejas. Sin embargo, es posible recurrir a las radiografías convencionales, el ultrasonido, las mamografías y la tomografía computarizada y emplear estas técnicas para abordar los problemas de salud de la mujer, como el cáncer de mama, el cáncer cervicouterino, las hemorragias puerperales y la tuberculosis. En los países de América Latina y el Caribe los servicios de radiología también tienen dificultades en lo que respecta a la calidad de los recursos humanos, los programas de garantía de la calidad y la normalización y funcionamiento de las unidades de imagenología. Estas deficiencias afectan la calidad de los servicios prestados. Es preciso adoptar medidas apropiadas para lograr servicios e imágenes de calidad y reducir los eventos adversos. Así se podrán obtener mejores resultados y, por ende, disminuir la mortalidad y la morbilidad.

Salud de la mujer; radiología; ultrasonografía; tomografía computarizada por rayos x; mamografía; América Latina; Indias Occidentales.

RESUMO Apesar dos Objetivos de Desenvolvimento do Milênio e da Agenda 2030 para o Desenvolvimento Sustentável das Nações Unidas, as mulheres em diversos países ainda enfrentam muitos desafios para obter assistência de saúde de boa qualidade. Vários países da América Latina e do Caribe não têm acesso às tecnologias de imagem complexas, porém eles dispõem de recursos de radiologia convencional, ultrassom, mamografia e tomografia computadorizada que podem ser usados para lidar com os problemas da saúde da mulher como o câncer de mama e o câncer do colo do útero, a hemorragia pós-parto e a tuberculose. Os países da América Latina e Caribe ainda enfrentam outras dificuldades nos serviços de diagnóstico por imagem como qualificação dos recursos humanos, prestação de serviços de qualidade e padronização e funcionamento das unidades. Essas deficiências comprometem a qualidade dos serviços prestados. Devem ser tomadas medidas adequadas para melhorar a qualidade dos serviços prestados e dos exames realizados e reduzir os desfechos adversos. Estas medidas podem assegurar resultados melhores com consequente redução da morbidade e mortalidade.

Palavras-chave Saúde da mulher; radiologia; ultrassonografia; tomografia computadorizada por raios x; mamografia; América Latina; Índias Ocidentais. 